\title{
O SONHO DE INGMAR BERGMAN: GRITOS E SUSSURROS, UMA MATERIALIDADE SIGNIFICANTE A COMPREENDER
}

\section{INGMAR BERGMAN'S DREAM: SCREAMINGS AND WHISPERINGS, A SINGIFICANT MATERIALITY TO UNDERSTAND IT.}

Taísa M. Pinheiro Silva

Faculdade de Filosofia, Ciências e Letras de Ribeirão Preto, USP, Ribeirão Preto, SP, Brasil

Elaine Pereira Daróz ${ }^{1}$

Faculdade de Filosofia, Ciências e Letras de Ribeirão Preto, USP, Ribeirão Preto, SP, Brasil

Dantielli Assumpção Garcia²

Universidade Estadual do Oeste do Paraná, UNIOESTE, Cascavel, PR, Brasil

Lucília Maria Abrahão e Sousa ${ }^{3}$

Faculdade de Filosofia, Ciências e Letras de Ribeirão Preto, USP, Ribeirão Preto, SP, Brasil

Resumo: Neste texto, objetivamos, mobilizando como perspectiva teórica a Análise de Discurso, analisar como o filme de Ingmar Bergman Gritos e Sussurros constrói suas personagens femininas, inscrevendo-as em uma tensão entre "revelar" e "ocultar" o seu (não) desejo de si.

Palavras-chave: Ingmar Bergman; Gritos e Sussurros; Feminino; Análise de Discurso.

Abstract: In this paper we aim to analyze the Ingmar Bergman's film Screamings and Whisperings build their female characters. Thus, we mobilize the theoretical perspective of Discourse Analysis in order to better understand the tension between "reveal" and "hide" their (no) desire inside themselves.

Keywords: Ingmar Bergman; Screamings and Whispering; Feminine; Discourse Analysis

Neste texto, intentamos produzir uma compreensão de Gritos

\footnotetext{
${ }^{1}$ Bolsista Pós-Doutorado Fapesp (Proc. N. 2018/13017-2).

${ }^{2}$ Bolsista Produtividade Fundação Araucária.

${ }^{3}$ Bolsista Produtividade 2 CNPQ.
} 
e Sussurros, filme de Ingmar Bergman, tendo como base a análise da constituição de suas personagens femininas e do modo como elas inscrevem, em uma tensão entre "revelar" e "ocultar", o (não) desejo de (si) para cena. Na perspectiva teórica da Análise de Discurso em articulação com a Psicanálise freudo-lacaniana, mobilizamos a noção de materialidade significante (LAGAZZI, 2007), isto é, entendemos as cenas do filme em "cuja materialidade específica (verbal, visual, sonora, gestual...) fica exposta à produção de significaçōes” (LAGAZZI, 2008, p. 01). Ainda para a autora, no significante - aqui não mais visto como imagem acústica, como na concepçáo saussuriana - estaria a composição de uma cadeia estruturante falha, uma abertura para a incompletude constitutiva das materialidades posta em funcionamento. Desse modo, cabe ao analista, em seu movimento de recorte, sendo este já um gesto de interpretação, buscar, na compreensão da materialidade significante, uma relação de movimento, de estabelecimento de relaçóes de sentidos de/sobre a mulher.

Gritos e sussurros é, talvez, um dos mais enigmáticos e sufocantes filmes de Ingmar Bergman; tido, por alguns críticos, como a obra-prima do diretor, para outros, é um verdadeiro filme de terror, dada a crueza dos sentimentos e relaçóes que materializam o mundo mental de suas personagens. $\mathrm{O}$ ambiente privado e intimista parece enclausurar ou encurralar suas personagens até arrancar o que há de mais dolorido nelas, sejam seus gritos, sejam seus sussurros, sejam também os impossíveis de gritar e sussurrar. Como em um pesadelo, somos atingidos pela profundidade e pelas incertezas. Poderíamos dizer de Gritos e Sussurros, em consonância com Carlos Gustavo Motta em seu livro Las películas que Lacan vio, que a perspectiva psicológica domina a trama narrativa e a composiçáo das personagens. A câmera não persegue as ações e sim os estados de ânimo e, sobretudo, as tensóes delas frente ao drama individual (MOTTA, 2013, p. 22). Para Oliveira Jr.:

Gritos e Sussurros, mesmo que imune a qualquer definição simplista, é em grande medida o filme de terror de Bergman. Há, de um lado, uma estratégia de desconforto atingindo seu ápice, e, do outro, um controle soturno das composiçôes e uma dramaticidade da cor que são dignas de Mario Bava. Nos seus melhores momentos, a mise en scène de Bergman nesse filme parece deter um segredo que ele se esforça em manter guardado, como um mágico que não revela seus truques, ou como a sabedoria inviolável dos antigos alquimistas. Tamanha prestidigitação depende da cegueira parcial da plateia, que não enxerga senáo um jogo de aparências, e todo o espaço do filme espaço sonoro e espaço-fora-da-tela mais do que incluídos - se vê assombrado por fantasmas que cobram sua parcela na ficção. A própria câmera age como um fantasma inquisidor, que espreme as personagens contra a parede até 
que elas devolvam ao filme uma expressão desejada (medo, vergonha, ódio, desespero). (OLIVEIRA JR., 2005, s.p.).

Toda essa composição soturna que ronda e dá forma ao filme inscreve o efeito de desconforto, essencial para a plástica da obra. Encurraladas na casa, nesse ambiente intimista e "espesso" de fechamento, é que as personagens náo param de se deparar consigo mesmas, sob o signo de segredos que o diretor se esforça para manter guardados. À maneira dos sonhos, que projetam imagens que visam a encobrir o objeto de desejo do sonhador e que comparecem como cifras e rébus (Freud o disse em diferentes obras) com elementos tidos como absurdos, Bergman faz falar os contornos imprecisos no âmago do desejo de suas personagens e, então, do contorno e dos arredores fantasmagóricos de seu inconsciente. Disso nasce a história em cujos efeitos de sonhos nebulosos as personagens são soterradas.

(...) Restos diurnos; acontecimentos, pensamentos e preocupaçóes que se ligam a um conteúdo inconsciente reprimido. Os restos diurnos não são capazes de produzir um sonho e o inconsciente precisa deles, para que o significado inconsciente do sonho não seja revelado. Por que é tão difícil entender os sonhos? Porque os sonhos vêm distorcidos e sem sentido, justamente para que a pessoa não entenda. Muito comum também é o esquecimentos de umas partes do sonho ao acordar, ou o esquecimento total, ao longo do dia (BITTENCOURT, 2010, s.p.).

Percepção importante é a de que o sonho atinge apenas ao sonhador, embora a obra de arte, de maneira fascinante e quando colocada em circulação, mostra-se a outros "sonhadores", deixando os rastros do trabalho feito pelo sujeito nos labirintos de seus sonhos. O cinema talvez venha no sentido de amenizar a solidão do nosso psiquismo, amenizar o que há de privado em nossos sonhos, colocando-nos a trilhar as pegadas dos sonhos junto com outros. Jean Cocteau, na introdução de seu filme Le testament d'orphée, diz que o privilégio do cinema é permitir a um grande número de indivíduos sonhar o mesmo sonho juntos e de apresentar a ilusão como se fosse pura realidade e que isto seria, segundo ele, um admirável veículo para a poesia. E Motta (2013) completa:

Las obras de arte son satisfacciones fantasmáticas de anhelos inconscientes, al igual que los sueños, con los que tienen en común el mismo carácter de compromiso. A diferencia de las producciones del sueńo - asociales y narcisistas -, las obras de arte eran concebidas para que otros hombres participasen de ellas y pudiesen suscitar y satisfacer en ellos las mismas 
emociones de deseos inconscientes (MOTTA, 2013, p. 23).

Em entrevista, Bergman teria dito que a composição dos elementos, texturas, cores e personagens poderiam ter sido mesmo um reflexo de fragmentos inconscientes ao tentar captar seu sentimento ambíguo e confuso pela própria mãe. Apenas essa afirmação do diretor já poderia despertar a fina atenção de um psicanalista, dada a efusáo de sentimentos que dessa relaçáo primeira e inaugural do sujeito poderia brotar; mas o filme se faz ainda mais interessante porque, e também à maneira dos sonhos, a composição dos personagens não é, em absoluto, literal. A genialidade do cineasta lidando com essa faceta misteriosa de seu inconsciente parece esculpir, ao desmembrar seus sentimentos ambíguos em relação à sua mãe, uma imagem do feminino, desse Outro, em suas várias nuances, frestas e contradiçôes. Nascem, então, suas quatro personagens principais do filme: Agnes, Anna, Maria e Karin.

\begin{abstract}
A ideia inicial era a seguinte: sentia que devia escrever alguma coisa sobre minha mãe, que morreu há alguns anos. Sempre tive com minha mãe uma relação ambivalente. Quando criança, era apaixonado por ela, mas depois, durante a puberdade - crescendo - esta forma de relação se transformou em algo completamente diferente. As relaçóes que tive com minha mãe sempre foram muito fortes, muito densas e há muito tempo tenho esta ideia bastante vaga de escrever alguma coisa e de fazer um filme sobre ela. Mas percebi que era mais fácil falar do que fazer. Eu simplesmente tinha muita dificuldade em exprimir algo de realmente sincero e objetivo a seu respeito. Fui perseguido, durante vários meses, por uma imagem: era um quarto vermelho - forrado de vermelho. Os móveis eram vermelhos. As cortinas duplas eram vermelhas. E neste aposento, havia três mulheres, todas vestidas de branco que caminhavam numa espécie de iluminação crepuscular... Era um fio saído do meu subconsciente - e comecei a fazer um novelo desse fio, e foi justamente o que deu essa história com as quatro mulheres. Foi só depois - através de um raciocínio posterior ao filme - que compreendi que o filme tratava profundamente de minha mãe. Eu a descrevi sob a forma de quatro mulheres diferentes (BJORKMAN; BERGMAN, 1977, p. 230).
\end{abstract}

Esse filme parece comunicar surdamente o que há de mais "orgânico" sobre o enigma mulher. As paredes de um vermelho sufocante matizam todo o filme, e mais parecem, como o próprio diretor ressalta, as paredes apertadas do útero. E essa observação não é qualquer observação. É notável na história das mulheres ocidentais, especialmente partindo de um discurso burguês, a associação da feminilidade ao ambiente privado, ao resguardo da circulação no espaço público, a uma esfera da maternidade e da procriação. Talvez 
o diretor quisesse também formular uma crítica aos grilhóes burgueses, ao espaço social delimitado que essas mulheres - e também sua mãe ocupavam. De acordo com Kehl (2008), o século XIX criou, na construção de um ideário (familiar) burguês, um antagonismo entre as convençôes sociais (as quais passam no domínio público) e a liberdade (da ordem do domínio privado) e isso produziu efeitos no modo de significar e inscrever simbólica e imaginariamente a figura feminina. Desse modo,

Para os homens, sobretudo, condenados a viver seu dia-a-dia na selva das cidades, a família tornava-se um lugar sagrado, cuja harmonia e tranquilidade estariam a cargo daquela que cada um escolheu para esposa (...) Devo me deter sobre a constituição deste lugar - a família nuclear e o lar burguês - tributária da criaçáo de um padrão de feminilidade que sobrevive ainda hoje, cuja principal função, como veremos, é promover o casamento, não entre a mulher e o homem, mas entre a mulher e o lar. A segunda funçáo da feminilidade nos moldes modernos foi a adequação entre a mulher e homem a partir da produçáo de uma posição feminina que sustentasse a virilidade do homem burguês.

A adequação das mulheres a estas funçóes foi fruto de uma enorme produção discursiva, como veremos logo adiante. Se hoje nos deparamos com uma ideia de feminilidade que nos parece tradicional é importante perceber que esta tradição tem uma história recente, que faz parte da história de constituição dos sujeitos modernos, a partir do final do século XVIII e ao longo de todo o XIX. Também é importante ressaltar que os discursos que constituíram a feminilidade tradicional fazem parte do imaginário social moderno, transmitindo através da educação formal, das expectativas parentais, do senso comum, da religiáo e da grande produçáo científica e filosófica da época, que determina o que cada mulher deve ser para ser verdadeiramente mulher. (KEHL, 2008, p. 44)

É um traço dessa "empreitada" burguesa que o espaço da familiaridade (e da feminilidade também), em que são mantidos as mais caras memórias e intimidades, seja o espaço doméstico, ou seja, a pátria da vida particular do sujeito moderno tem como pilar e sustentáculo as mulheres. A vida íntima do sujeito, sua espontaneidade e sentimentos mais profundos dificilmente irão romper a barreira do espaço doméstico e se evidenciar nos espaços públicos; dito de outro modo, o espaço privado é, por excelência, o espaço de gestação do sujeito e nele estão situadas as mulheres. Não à toa que o filme trata da relação de três irmãs, todas geradas dentro de um mesmo "útero" burguês e uma criada, que náo segue as normas da moral e da educação desejada pela burguesia, e que, no entanto, ali naquele contexto, parece ser a única capaz de amar com espontaneidade e doaçáo. 
É nítido, então, que essas relaçôes familiares intrincadas denunciem padrôes caros à posição daquela família e também à época. O que não é nítido em um primeiro momento, e que precisa de um acesso "aos bastidores", é que o lar que Ingmar Bergman crescera, em muito se parecia com o retratado no filme e o próprio cineasta chegou a defini-lo como o "mais conservadores que os conservadores". Estamos diante de uma estrutura cuja moral mantemse extremamente rígida, marcada pelo funcionamento ideológico patriarcal, engessada por papéis e lugares sociais sem mobilidade, na qual os desejos (e desejar, que talvez seja o traço mais característico do ser humano) são duramente reprimidos. Não devemos deixar de notar que o filme, apesar de não estipular uma data precisa, possivelmente se passa no século XIX, com alguma margem de erro para final do século XVIII ou início do século XX. A atemporalidade dá autenticidade ao filme, o faz mais onírico, já que temos de Freud (1927/1969) a anotação de que o inconsciente náo é temporal, mas define seu "misterioso" fluir, que nada tem de linear.

\footnotetext{
Sobre isso, Freud já nos diz que o inconsciente é atemporal, ou seja, desconhece o tempo. Em O mal estar na civilização (1927/1969), ele nos explica como se dá o tempo para o inconsciente e compara a vida mental com a cidade de Roma, a "cidade eterna". Nessa cidade, as ruínas do passado se mesclam com o desenvolvimento da grande metrópole e vestígios de diferentes fases podem ser trazidos à luz. Porém, enquanto na cidade há apenas vestígios e restos do passado, na vida mental nada é destruído com o tempo e as primeiras fases do desenvolvimento se mostram intactas, conjugam-se com o que se atualizou, e "o elemento primitivo se mostra preservado ao lado da versáo transformada que dele surgiu” (FREUD, 1927/1969, p. 77). (COSTA, 2001, p. 02).
}

Um filme que trata da incomunicabilidade e da impenetrabilidade das almas e coloca a mulher aí, como Gritos e Sussurros, e que se utiliza dessa atemporalidade parece ter o silêncio como um fantasma que paira sobre a casa. Nesses termos, os diálogos são escassos, as cenas são lentas, os rostos transmitem a história, e disso deriva o efeito de poesia obscura de cada personagem. Não é novidade que, para Bergman, o rosto é um grande quadro, um grande palco, em que as expressóes pintam os sentimentos formando uma estética única. As duas cenas abaixo indiciam tal funcionamento. 


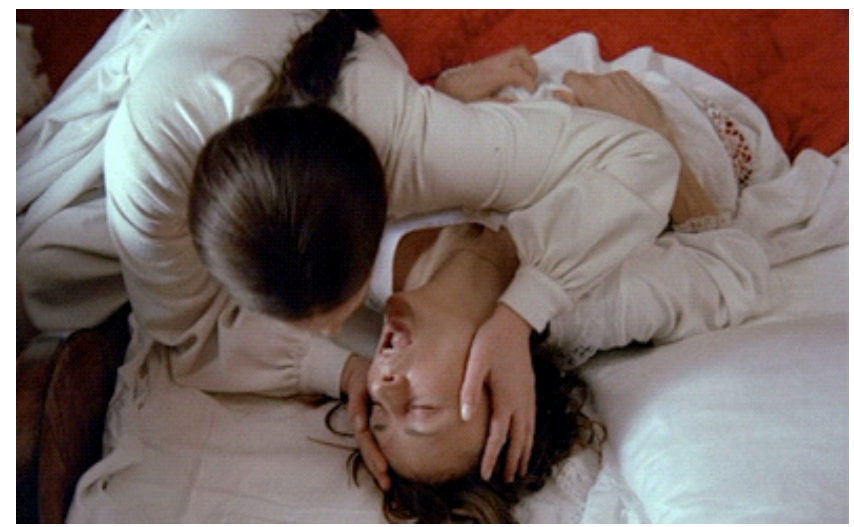

Figura 1: Kari Sylwan (Anna) e Harriet Andersson (Agnes).

Fonte: Foto das autoras capturada do filme Gritos e Sussurros.

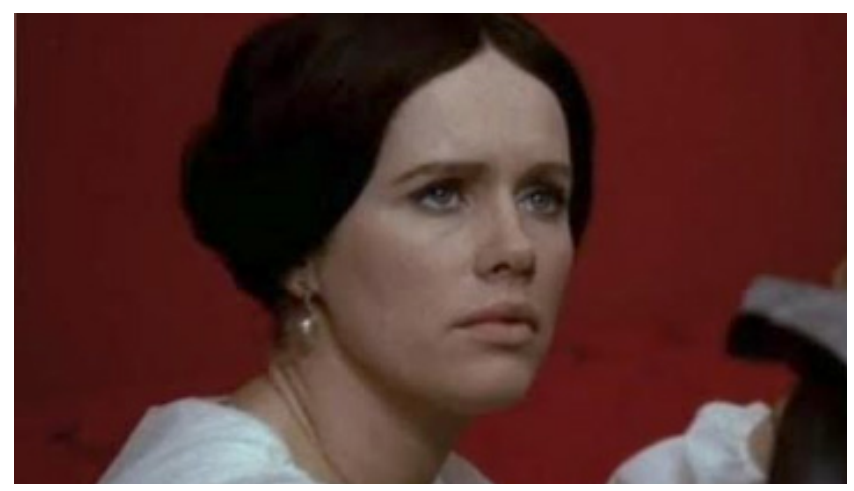

Figura 2: Liv Ullmann (Maria).

Fonte: Foto das autoras capturada do filme Gritos e Sussurros.

A composição da cena tem o rosto como ponto principal, seja pelo modo como ele é enquadrado e posicionado, seja pela luz que incide sobre ele, seja pelo modo como a mudez é instada a uma condição de grito. De acordo com Ribeiro:

O rosto é o palco (...) Bergman prova que o habitat da emoção do ator é seu rosto, fazendo com que vejamos a tela cheia de enormes rostos que falam 
e, principalmente, ouvem, reagindo às palavras quase sempre antagônicas. A câmara está sempre muito perto, mostrando bocas, ouvidos e olhos. A propósito, notem o título de alguns filmes de Bergman: "O Rosto" (Ansiktet), "Face a Face" (Ansikte mot ansikte) e "Persona" (máscara em grego). O homem era fascinado por rostos! O escritor Fernando Monteiro — imenso admirador de Bergman — reivindica para Joseph von Sternberg a compreensão da força da face humana na tela. (RIBEIRO, 2009, s.p.).

Neste filme em especial, o gosto do diretor por rostos assume contornos especiais; é o olhar que assume majoritariamente o dizer, atravessado por uma condiçáo de calamento da palavra e de abertura para que os sentidos possam deslizar e bascular entre o horror e a densidade. A proximidade da câmera parece exercer uma pressão esmagadora, inquiridora sobre as personagens, obrigando-as a colocar o rosto no centro da cena, inscrevendo um outro modo de dizer. A voz está impedida na mesma medida em que os olhos, a pele e os traços singulares da face contam algo de incalculável para as palavras. Os olhos na obra ultrapassam sua função orgânica do ver, estão, sim, atrelados a um desejo que não é óbvio nem restrito a uma função do órgão. O desejo, aqui, é o de alcançar o outro em sua névoa de incomunicabilidade, criando a tentativa de transmissão que a linguagem nem sempre supre; assim, podemos dizer que o olhar, aqui, contorna o Real a fim de inscrever algo impossível para a voz e para a palavra, tanto é que a sensação de angústia é nítida, e o uso desse efeito cinematográfico parece cumprir grandemente seu papel. Nesses termos, as personagens restam encurraladas entre o dito e o impossível de dizer, refletidas na clausura que o ambiente causa, entregues à solidão de seu próprio psiquismo, à impenetrabilidade do outro e à impossibilidade de uma comunicação verdadeira, para além da suposição de palavras do outro. Como afirma Oliveira Jr. (2005):

Bergman é sem dúvida um dos grandes estetas do close-up cinematográfico, e aqui seu teatro de fisionomias adquire uma carga extra de significação: Gritos e Sussurros é uma anatomia de rostos femininos, estudados tanto em sua materialidade quanto em seus investimentos subjetivos. E esses rostos, ao menos para Bergman, são "contos de terror", daí seu teatro de fisionomias se desdobrar numa performance da crueldade, encenada com marionetes que sofrem de um desespero magoado e, muitas vezes, contido, quando apenas sussurrado. (OLIVEIRA JR., 2005, s.p.)

Esse fascínio do cineasta por rostos e, sobretudo, pela complexidade da alma se manifesta - seus micro e macrocosmos - em seus personagens 
e ambientes tidos culturalmente como femininos. Em Gritos e Sussurros, especialmente, Bergman parece sondar pela fechadura as nuances e os mistérios de cada mulher ali presente, ultrapassando os elementos tidos como "femininos" ou "masculinos", produzindo um efeito do universal da condição do humano faltante e precário, como afirmam Bjorkman e Bergman (1977):

Não, não acredito. (que as mulheres, enquanto seres humanos, são mais interessantes do que os homens). Talvez, fosse verdade há alguns anos, mas hoje em dia, náo faço mais essa diferença entre masculino e feminino sinto nossos problemas de uma forma humana em geral. Simplesmente (...) Quanto mais explorei o mundo das mulheres, mais percebi que ele era idêntico, sob vários pontos de vista, ao meu próprio mundo. Quanto mais as mulheres se tornaram amigas - como os homens - mais esta ambivalência se atenuou. Sinto um prazer enorme em trabalhar com atrizes. Isto quer dizer que, às vezes, ao invés de utilizar um homem para fazer uma espécie de autorretrato, por exemplo, apelo para uma mulher. Neste caso, acho que a máscara é perfeita. Porque na verdade o que existe são só problemas humanos. Não há tantas questôes puramente masculinas ou puramente femininas como pensava antes. Em Gritos e Sussurros o conteúdo é puramente humano - o acento não é colocado especificamente ao lado das mulheres. Há, certamente, no filme, passagens "femininas" fortemente acentuadas (BJORKMAN; BERGMAN, 1977, p. 232, 236).

Um dos pontos do filme em que as questóes de gêneros tocam essa esfera do "puramente humano" merece destaque na cena abaixo, na qual o diretor nos presenteia com uma Pietá, senão uma das mais emocionantes e provocadoras imagens de seu cinema.

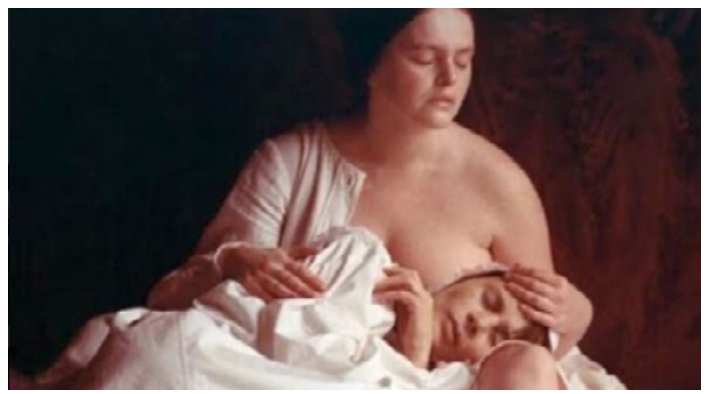

Figura 3: Kari Sylwan (Anna) e Harriet Andersson (Agnes).

Fonte: Foto das autoras capturada do filme Gritos e Sussurros. 
A Pietá de Ingmar Bergman reproduz o amor agápico, um amor espontâneo e incondicional que denota doação e deixa entrever em si mais indistinta empatia pelo outro, bem como a piedade cristá da Pietá de Michelângelo Buonarrotti. Mas as analogias e ousadias náo param aqui, vejamos um pouco mais sobre a obra renascentista que nos ensejará a comparaçóes. A dualidade ao se falar sobre as mulheres é intensamente reiterada no cristianismo por este maniqueísmo: ou é vista como a virgem em sua total pureza - e ironicamente a máe dotada de amor e doçura incondicionais - ou é a mulher perversa, sedutora que induz o homem ao pecado e espalha a desgraça sobre a terra, e, por isso mesmo, deve logo ser reprimida. No filme, há personagens que, em uma possibilidade de interpretação, poderiam se encaixar nessa dualidade: Anna e Maria, respectivamente. Para adentramos mais as concepçóes de Bergman sobre as nuances da imagem da mãe, é preciso que analisemos personagem por personagem, e que, como emanaçôes inconscientes que o são, não deixam, contudo, de se atrelar aos símbolos veiculados culturalmente, nem como não se apresentaram de maneira linear. Parece-nos que cada uma precisa da outra para existir, apenas seus corpos são delimitados - e talvez esse recorte que o corpo fosse essencial para os contornos e rodeios de Bergman em seu desejo central: retratar a mãe e sondar suas questóes com a feminilidade -, mas suas histórias e emoçóes são entrelaçadas.

Anna, a criada, que em visão ou sonho ouve e atende o chamado da já morta Agnes, é a única capaz de manifestar amor - um amor instintivo, natural, ladeado de ternura e piedade - naquele ambiente doentio de silêncio e de repressóes sentimentais. Ela toma Agnes em seu colo encostando-se a seu corpo, transmitindo o calor emocional que aquele outro corpo precisa para se curar da doença da incomunicabilidade ou do desamparo - que marca de maneira tão universal nossa "condição humana". Nesses termos, Anna é, muitas vezes durante o filme, humilhada, ofendida; todavia, é capaz de perdoar ilimitadamente, é capaz mesmo de suportar a angústia da perda de sua criança sem definhar na amargura. Essas características fazem dela muito próxima da figura de Maria e dos princípios de amor, compaixáo e perdão caros ao cristianismo. 


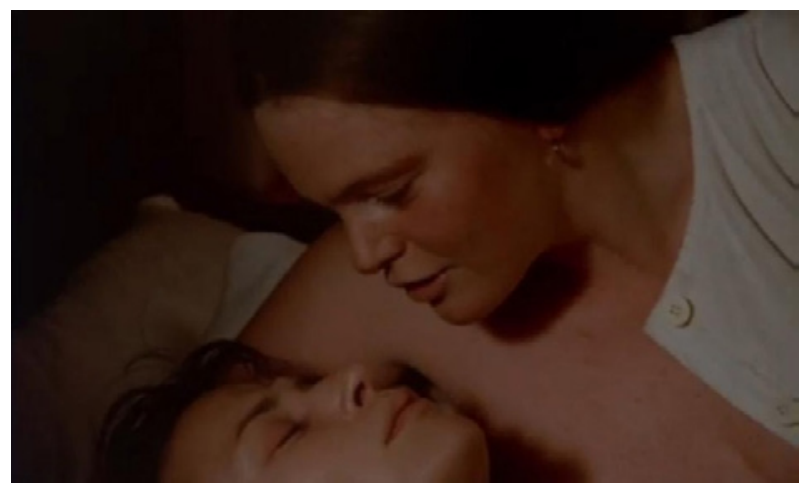

Figura 4: Kari Sylwan (Anna) e Harriet Andersson (Agnes).

Fonte: Foto das autoras capturada do filme Gritos e Sussurros.

Guilhardi (2001) afirma que:

Anna dá o que Agnes precisa para se acalmar - o sereno toque do amor, a aceitação incondicional da menina desamparada - e revela o sentimento que nutre por ela: piedade. Numa ação inesperada, Anna aconchega Agnes morta. Compóe em atos lentos - como compete ser a cena do Amor - o encontro do seu corpo com o de Agnes para esculpir com gestos a Pietà de Bergman. Ali estáo contidos a dor de Agnes que se esvai com a vida, o amor agápico de Anna que náo interrompe, mas alivia o estertor da morte, a piedade da mater dolorosa - Anna é a mãe que poderia ter salvo Agnes - e a dor de Anna evocada pelo fim de um genuíno amor, selado pela morte. Que síntese de sentimentos através do equilíbrio de gestos! (GUILHARDI, 2001, p. 05).

Podemos supor, diante dessa nossa compreensão da materialidade significante do filme, que talvez o que há de genuíno no amor de Anna venha de uma criaçáo diferente da qual as três irmãs tiveram no seio de uma abastada família burguesa de moral rígida. A educação das irmãs reflete traços profundos de seus comportamentos e cada uma delas manifesta a falta de liberdade e esse "engessamento" social de uma maneira, mas se há algo compartilhado por todas é a relação bastante conflituosa no que tange a dar e receber afeto. Como afirma Belém Júnior (2002):

Bergman sempre dedicou o melhor de sua criatividade ao universo feminino. Em entrevistas, dirá ele que Anna é uma nova personagem feminina que aparece em sua obra. Não por acaso, aparece num momento da carreira em 
que o diretor se dispóe a criticar, eficientemente, uma sociedade burguesa extremamente conservadora, punitiva, orientada por dogmas religiosos, em que o sexo era tabu e o comportamento, rigidamente disciplinado. Anna, que inferimos ter sido educada num universo diferente daquele, liderado pela mãe que mete medo às filhas, não desenvolve as neuroses das três irmâs e pode amar com naturalidade que a burguesia desconhece (BELÉM JÚNIOR, 2002, p. 124).

E se Anna encarna Maria, Agnes representaria Jesus? Mas Agnes é uma mulher - tantas vezes menosprezada e acusada na dualidade cristã - e é humana, sua dor é extremamente humana, está despojada de qualquer aura sagrada.

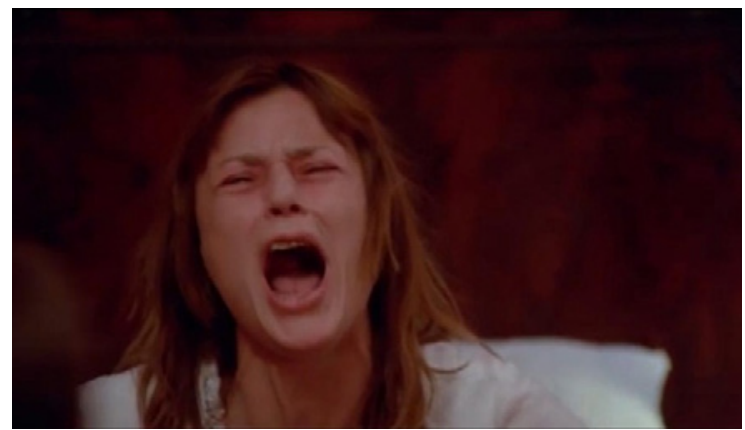

Figura 5: Harriet Andersson (Agnes).

Fonte: Foto das autoras capturada do filme Gritos e Sussurros.

Poderíamos, inclusive, dizer que ela nos expóe o que há de mais humano em nós: o desamparo, a necessidade de cura pelo afeto, a força extrema, a consciência dos limites de corpo orgânico. O que Ingmar Bergman quereria com esse "joguete"? É possível que ele nem tenha querido dizer nada em especial, é possível que, sob o julgo de nossa interpretação, ele tenha brincado com os signos, expondo alguns deles para quebrá-los; ensinando-nos a fugir dos lugares-comuns que soterram o senso crítico, colocando em circulaçáo apenas o enigma para que cada um possa fisgar dele o que lhe seja possível.

O nome de Agnes, coincidentemente ou não, tem origem comum ao de Santa Inês, uma das virgens responsáveis por manter o fogo sagrado dedicado à Vesta, a deusa romana que simboliza o lar. Naquele ambiente privado e "orgânico", em que, muitas vezes, todas as personagens circulam, 
em um ballet doloroso, vestidas de branco, como as vestais, é Agnes quem implora pela manutenção de um vínculo familiar, de um "fogo" que rompa a frialdade dos elos. $\mathrm{Na}$ Roma antiga, era esse fogo sagrado unido ao culto aos antepassados que mantinham a unidade do núcleo familiar. E ressaltemos, aqui, que a família em Roma é bastante diferente da família mononuclear burguesa. Praticamente toda a vida privada em Roma estava estruturada em função da manutenção desses deuses do lar. Agnes, de maneira análoga, é a única das irmãs realmente desejosa da união familiar. É ela também que experimenta uma consciência plena da doença daquele ambiente, ela está, nas palavras de Fernando Pessoa (1930-1935), lúcida como se estivesse para morrer. Por isto, é a única a manifestar gratidão, vicissitude tão difícil de alcançar ali, e vislumbrar momentos de felicidade - representados no filme por um ambiente externo a tal casa, em que as cores não mais oprimem, mas dão a sensação de leveza e harmonia e em que todas as irmãs caminham juntas no jardim em um clima outonal. Sua fé - e na cena da extrema unção, o padre revela ter sido a fé dela maior que a dele próprio - a faz suportar suas dores e angústias, há um sentido de resiliência - e uma coragem extrema na personagem que ajudam-na a compor seu caráter humano, demasiadamente humano.

Já a personagem de Maria parece vir completar aquela dualidade de posiçóes femininas a que nos referimos, ela representaria Eva. Com comportamentos muitas vezes pueris, Maria é bela, jovem e cede aos seus desejos, curiosidades, inclusive tivera um caso extraconjugal; e há no filme referência à tentativa de suicídio do marido por este motivo. À moda da personagem bíblica, ela cai em "tentaçôes", clama por amor, amor, contudo, que não sabe oferecer.

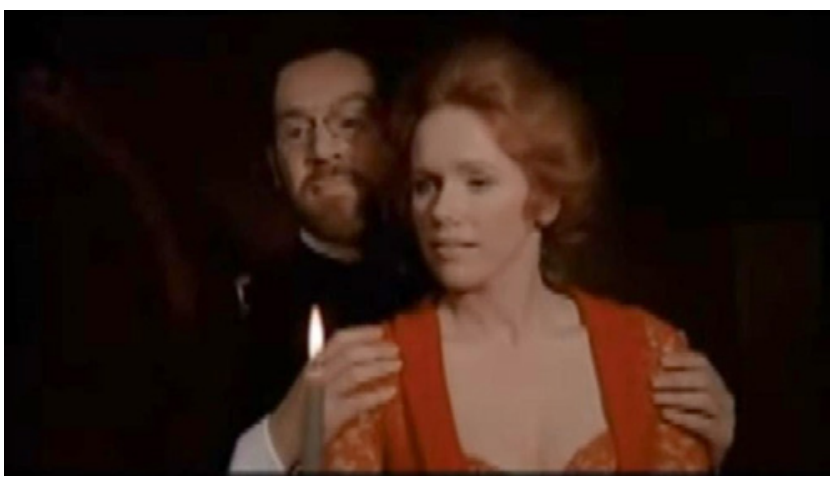

Figura 6: Liv Ullmann (Maria).

Fonte: Foto das autoras capturada do filme Gritos e Sussurros. 


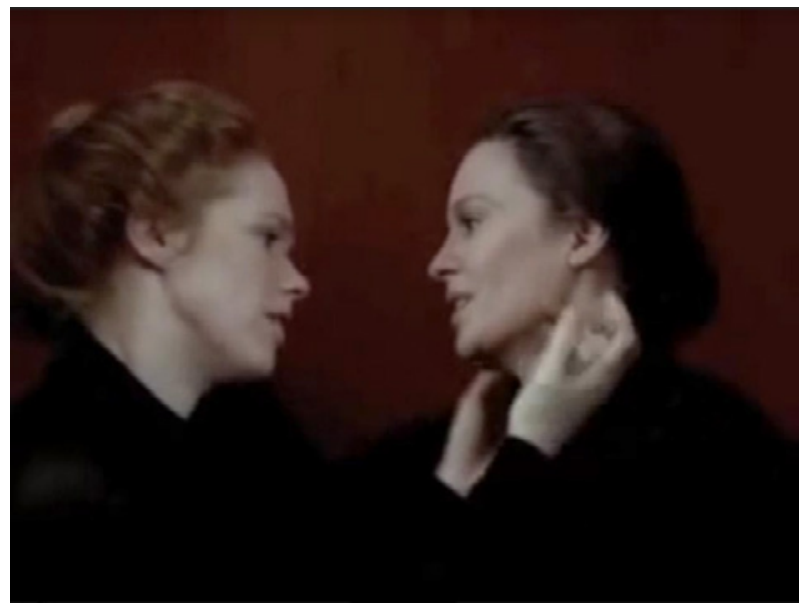

Figura 7: Ingrid Thulin (Karin), Liv Ullmann (Maria).

Fonte: Foto das autoras capturada do filme Gritos e Sussurros.

Quando chamada pela irmã, Agnes, que não sabemos se apenas se tratava de um sonho de Anna, parece atendê-la em um primeiro momento, mas quando sente a morbidez perto de si, foge horrorizada. Seu comportamento ao longo do filme a faz parecer a mais "frívola" das irmãs, guardadas as proporçôes de sua rígida educação. Não raro suas atitudes podem transmitir algo de artificial como seu choro copioso na morte da irmã ou a aproximação forçada que tenta com Karin. Assim, ela reúne muitas características que nossa cultura costuma atribuir de maneira pejorativa à mulher. Karin, talvez a personagem mais complexa, ao contrário, é a única a qual são atribuídas determinadas características tidas como masculinas. Ela se apresenta rígida, segura, é ela quem comanda a casa e as demais propriedades, bem como outras formalidades como o enterro de Agnes. Ela incorpora o poder. Surge a nós então uma pergunta bastante válida: a mulher precisa necessariamente incorporar determinados elementos atribuídos aos homens para atingir o poder? 


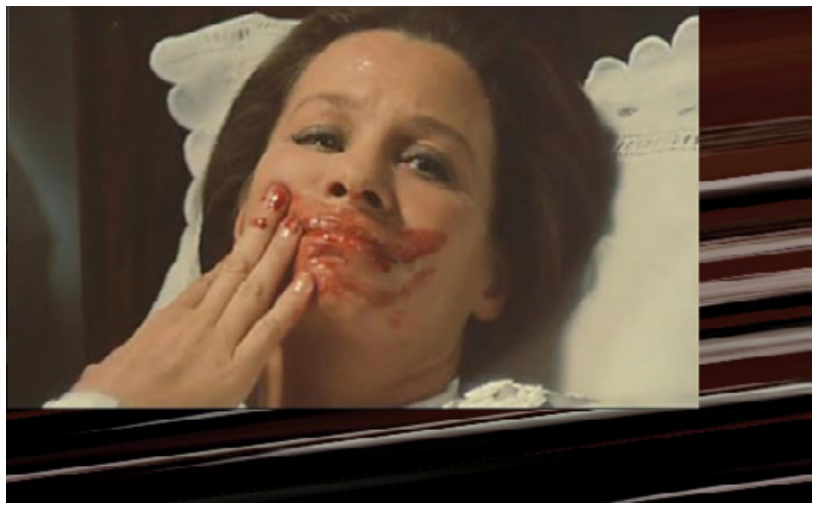

Figura 8: Ingrid Thulin (Karin), Liv Ullmann (Maria).

Fonte: foto das autoras capturada do filme Gritos e Sussurros.

O fato de pertencer e, principalmente, de encarnar os preceitos burgueses da época, faz de Karin um personagem quase caricatural da mulher reprimida sexualmente, sufocada pelos pilares da religião, presa a um casamento frio e sem qualquer expressão de amor, que parece na realidade uma grande encenação. Vale ressaltar, aqui, a cena em que ela janta com seu marido em silêncio, repetindo para si que aquilo tudo náo passa de uma grande mentira. O fato de Karin repetir incessantemente para si que tudo ali é uma mentira intensifica o tom de encenação de sua própria vida, que parece sucumbir em um discurso prêt-à- porter que nela se instala náo sem pressóes sociais. Mas que também nela revela um desejo de interromper essa teatralidade e alcançar discursos próprios.

Seguir com o que demandam dela faz com que ela seja mais uma das propriedades de seu marido, um igualmente rígido, austero, um taciturno diplomata que parece transmitir pelo olhar seu poder sobre ela, a reificando. O discurso de Karin, bem como seu próprio ser, está fragmentado - em cacos - como uma taça de vinho que ela quebra em uma cena de jantar. $\mathrm{Na}$ visão burguesa da época só o casamento poderia purificar a mulher, mas era o casamento o que ajudava a adoecer Karin por dentro. Sua dor se faz visível em uma cena memorável, com o cristal da taça quebrada, Karin se corta, corta sua vagina. Abaixo o corte e o sangue materializam esse ponto em que o feminino se dá a ver de modo escancarado pelo impossível de dizer com palavras, um apontamento do real inscrito no corpo. 


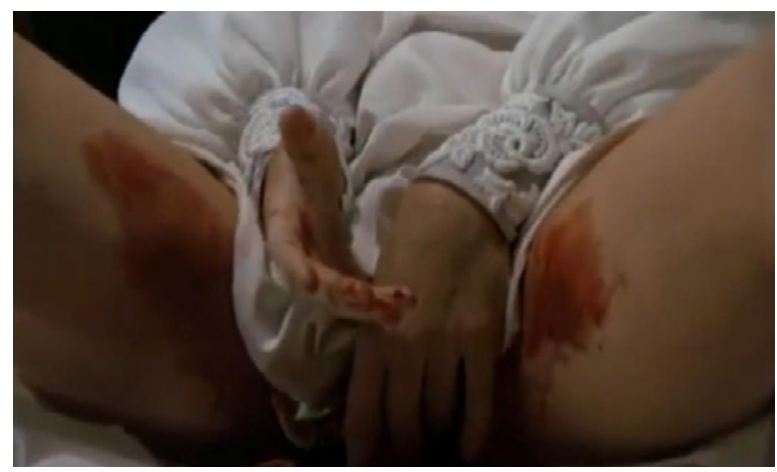

Figura 9: Ingrid Thulin (Karin).

Fonte: Foto das autoras capturada do filme Gritos e Sussurros.

Nessa cena densa, há um desespero, mas também um gozo, uma espécie de libertação, como se, por um instante, ela conseguisse se despojar de suas ataduras e seu imenso ódio interno. Na cena seguinte, em que ela deveria "cumprir suas obrigaçôes como esposa", de maneira muito simbólica, passa o próprio sangue em sua boca. Manter-se silente, remoendo seu ódio, já a feria há muito tempo. Sua feminilidade bem como sua existência se mostram adoecidas, cortadas de modo a deixar a ferida aberta, a pele rasgada, a carne exposta. Aqui, a personagem quebra o ritmo de sua vida encenada, fazendo funcionar o sangue na vagina e na boca, ou seja, nos orifícios marcados pela dor e pelo insuportável dizer; nisso ela se coloca.

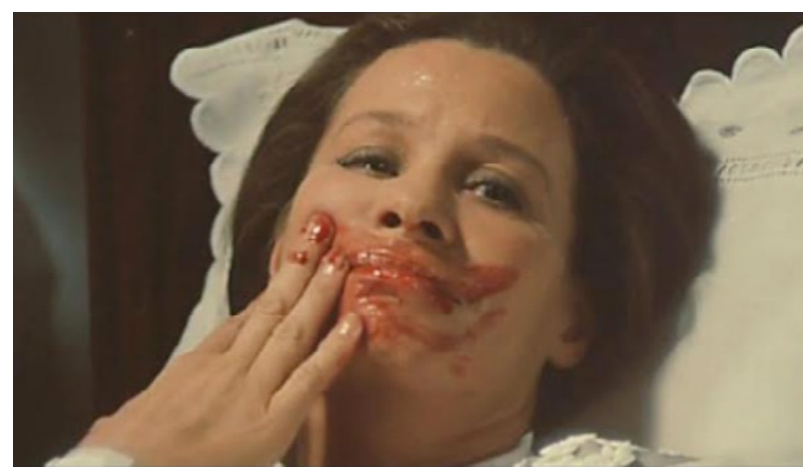

Figura 10: Ingrid Thulin (Karin).

Fonte: Foto das autoras capturada do filme Gritos e Sussurros. 
A personagem demostra repulsa em ser tocada ou receber e dar afeto, por isso se nega com veemência a atender a súplicas de Agnes, diz prontamente que não a ama e não quer qualquer ligaçáo com a morte da irmã. Karin é incapaz de amar, humilha Anna diversas vezes, foge com pavor da tentativa de aproximaçáo de Maria. Ela está silente, endurecida por seus claustros e só consegue espalhar sua mágoa nas relaçóes. Como questiona Guilhardi (2001):

$\mathrm{O}$ que se poderia esperar das irmãs de Agnes? Elas foram vítimas de contingências análogas, que selecionaram padrôes comportamentais funcionalmente semelhantes (possivelmente menos destrutivos). Que dizer de Karin que se mutila com os cacos de cristal? De Marie, que frivolamente busca a conquista: ter, nunca dar? Como dar amor se Karin rejeita a aproximação física de Marie? "Me deixe em paz", diz ela. O didático "fading in" de toques e falas que Marie emprega com Karin - numa longa e encantadora cena do filme - consegue produzir o encontro, mas a relação não é incorporada por Karin. Seduzida pela força do procedimento de Marie, Karin se entrega ao abraço, mas o comportamento mal instalado de se relacionar com a irmã náo se mantém. Nem mesmo Marie está apta para manter-se próxima da irmá. A relação afetiva entre elas é possível, mas improvável. Ao se despedirem, após o funeral, os ressentimentos voltam a reger os mimetizados movimentos de separação, mimetizados por movimento de carinho, mas sem função afetiva (GUILHARDI, 2001, p. 10).

Gritos e Sussurros, como o próprio nome sugere, fala da incomunicabilidade, dos vários tipos de silêncios, do impossível e do impedimento de colocar em palavras afetos do horror, da violência e da morte, que as mulheres estavam submetidas e que estamos também hoje quando vemos, ainda, tantas mulheres se submeterem a situações de claustros em suas vidas. O filme inscreve uma poesia profunda e agressiva, extremamente claustrofóbica sobre as relaçóes de poder, tocando a força dos sentimentos, afetos e traumas da condição humana em sua relação com a linguagem e com os outros. Também toca os efeitos de sutileza, beleza e anseio de liberdade, que aparecem especialmente durante a cena em que as irmás e Anna passeiam ao ar livre todas vestidas de branco em uma cena pitoresca e bucólica. Trata-se de um momento catártico, de expurgação do ambiente sufocante e das dores latentes e que nos fala diretamente sobre um processo de sublimação. 


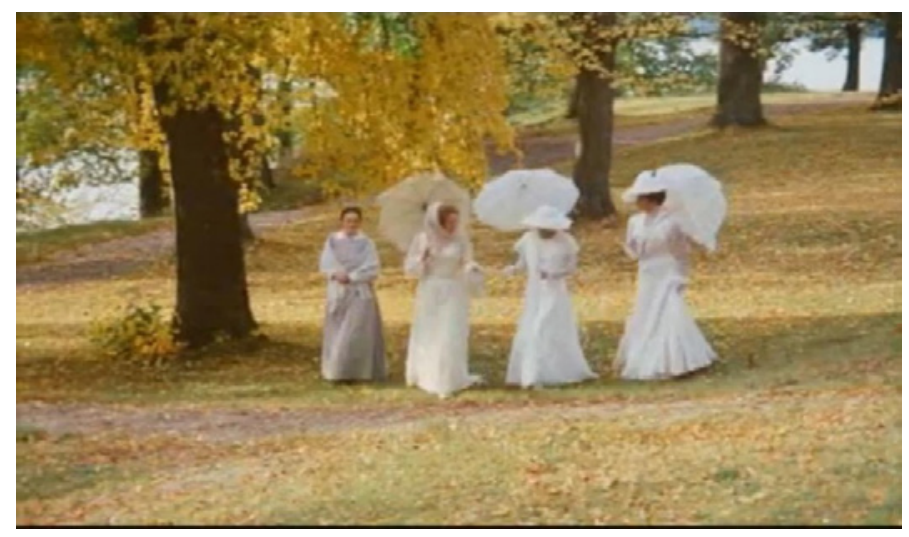

Figura 11: Ingrid Thulin (Karin), Kari Sylwan (Anna), Liv Ullmann (Maria) e Harriet Andersson (Agnes).

Fonte: Foto das autoras capturada do filme Gritos e Sussurros.

E se temos o aval para construir analogias, será que este ambiente externo não é comparável a um sonho quando exteriorizado e mais brilhantemente quando traduzido de forma artística com sua carga de intimidade tentando alcançar algo de uma extimidade? Ou não é válida a afirmação de Benjamin: "o cinema introduziu uma brecha na velha verdade de Heráclito segundo a qual o mundo dos homens acordados é comum, o dos que dormem é privado" (BENJAMIN, 1994, p.190). Utilizando-se do microcosmo da família e das tensas relaçóes entre seus integrantes, e de excelentes personagens femininas, Ingmar Bergman instala e transcende as secçôes entre os sexos. Existem elementos no filme que tratam especificamente dos modos de constituição da mulher e da voz feminina, se assim podemos falar. Mas há um atravessamento que tateia o que é próprio de sujeitos homens e mulheres, qual seja, o insuportável do sexo e da morte, fazendo falar a não proporção a que está fadado o humano; nesses termos, nos deixa sempre frente ao enigma típico de uma grande obra de arte e da poesia. Motta (2013) nos diria que a obra de arte, em si, é um enigma como o da Esfinge que constitui o primeiro passo na busca incessante e mortífera da verdade. Nesses termos a obra de arte e o filme de Bergman sinalizam uma saída possível ao horror fundante de cada um. 


\section{Referências}

BELÉM JÚNIOR, L. O inconsciente segundo Ingmar Bergman, Goiania, v. 5, n. 1/2, p. 119-127, 2002. Disponível em < http://www.revistas.ufg. br/index.php/ci/article/view/24176>. Acesso em: 30 jun. 2019.

BENJAMIN, W. A obra de arte na era de sua reprodutividade técnica. Porto Alegre: Ed L\&Pm, 1994.

BITTENCOURT, D. Os sonhos e a vida psíquica. 2010. Disponível em $<$ http://danielabittencourt.blogspot.com.br/2010/10/os-sonhos-e-vidapsiquica.html >. Acesso em: 30 jun. 2019.

BJORKMAN, S.; MANNS, T.; SIMA, J. O cinema segundo Bergman. Rio de Janeiro: Paz e Terra, 1977.

BRANCO, J. L. de C. C. A angústia na obra de Ingmar Bergman: Sarabanda em ser e o tempo de Heidegger. Dissertação (Mestrado em Artes). Universidade Presbiteriana Mackenzie, São Paulo, 2009. <http://www.educadores.diaadia.pr.gov.br/arquivos/File/2010/artigos_teses/2010/Arte/dissertacao/filme_ing_berg.pdf >. Acesso em: 30 jun. 2019.

COSTA, L. A. O que não cessa de se atualizar. Almanaque online. Minas Gerais, Instituto de Psicanálise e Saúde Mental de Minas Gerais, n 6. , p. 1-5, 2001. Disponível em: < http://almanaquepsicanalise.com.br/wp-content/uploads/2015/09/loren.pdf>. Acesso em: 30 jun. 2019.

EWALD FILHO, R. Gritos e Sussurros. Revista Ingmar Bergman. Rio de Janeiro, $1^{a}$ ed. Centro cultural Banco do Brasil, Jurubeba produçôes, 2012. GUILHARDI, J. H. O toque do amor em um universo de linhas paralelas: Gritos e Sussurros de Ingmar Bergman. Campinas: Instituto de terapia por Contingências e reforçamento e Instituto de Análise do Comportamento, 2001. Disponível em < http://www.itcrcampinas.com.br/txt/gritosesussurros.pdf $>$. Acesso em: 30 jun. 2019.

HOLMBERG, J. Presidente da Ingmar Bergman Foundation. Revista Ingmar Bergman. Rio de Janeiro, $1^{\text {a }}$ ed. Centro cultural Banco do Brasil, Jurubeba produçôes, 2012.

KEHL. M. R. Deslocamentos do Feminino. 2. Ed. Rio de Janeiro: Imago, 2008.

LAGAZZI, S. O recorte significante na memória. In: Seminário de Estudos em Análise do Discurso. Anais do Seminário de Estudos em Análise do Discurso, Porto Alegre: UFRGS, 2007. 
. A equivocidade na imbricação de diferentes materialidades significantes. Disponível em <http://dlm.fflch.usp.br/sites/dlm.fflch.usp.br/files/ Suzy\%20Lagazzi.pdf>. Acesso em: 30 jun. 2019.

MAGALHÃES. S. C. Cinema, sonho, psicanálise. Cogito, Salvador, v. 9, n. 9, p. 86-90, 2008. Disponível em: < http://pepsic.bvsalud.org/scielo. php?pid=S151994792008000100019\&script=sci_arttext>. Acesso em: 30 jun. 2019.

MELO, W. C. V.; GUIMARÃES, A. H. T. Entre as palavras e a pedra: Pietà. Revista Anagrama: Revista Científica Interdisciplinar da Graduação, São Paulo, Ano 4, Ed. 2, p. 1-15, Dez. 2010/Fev. 2011. Disponível em < http://www.revistas.univerciencia.org/index.php/anagrama/article/viewFile/7279/6578>. Acesso em: 30 jun. 2019.

MOTTA. C. G. Las películas que Lacan vio y aplicó al psicoanálisis. 1 ed.- Buenos Aires: Paidós, 2013.

OLIVEIRA JR, L. C. Gritos e sussurros. Revista Contracampo. Edição 74. Disponível em < http://www.contracampo.com.br/74/gritosesussurros. htm>. Acesso em: 30 jun. 2019.

PESSOA, F. “Tabacaria”. In: . Obra poética. Rio de Janeiro: Nova Aguilar, 1995.

. Poesias Inéditas (1930-1935). Lisboa: Ática, 1955.

ORLANDI, E. “Segmentar ou recortar?”. Lingüística: questōes e controvérsias. Série Estudos 10. Curso de Letras do Centro de Ciências Humanas e Letras das Faculdades Integradas de Uberaba, 1984.

RIBEIRO, M. Sobre Gritos e Sussurros, de Ingmar Bergman. 2009. Disponível em <http://miltonribeiro.sul21.com.br/2009/07/03/sobre-gritos-e-sussurros-de-ingmar-bergman/>. Acesso em: 30 jun. 2019.

ROBACH, M. Embaixador da Suécia no Brasil. Revista Ingmar Bergman. Rio de Janeiro, $1^{\text {a }}$ Ed. Centro cultural Banco do Brasil, Jurubeba produçóes, 2012. 